\title{
Evaluation of some environmental and genetic factors (CSN3 and AGPAT6 gene) on milk yield and composition in Saanen goats
}

\author{
Deniz Dincel $^{1 *}$, Sena Ardicli ${ }^{1}$, Hale Samli ${ }^{1}$, M. Mustafa Ogan ${ }^{2}$, and Faruk Balci ${ }^{1}$ \\ ${ }^{1}$ Department of Genetics, Bursa Uludag University, Faculty of Veterinary Medicine, Bursa, Nilufer, Turkey \\ ${ }^{2}$ Department of Zootechnics, Bursa Uludag University, Faculty of Veterinary Medicine, Bursa, Nilufer, Turkey
}

DINCEL, D., S. ARDICLI, H. SAMLI, M. M. OGAN, F. BALCI: Evaluation of some environmental and genetic factors (CSN3 and AGPAT6 gene) on milk yield and composition in Saanen goats. Vet. arhiv 91, 19-30, 2021.

\begin{abstract}
This study was designed to determine the effect of some environmental factors on milk yield and composition in Saanen goats and the effect of CSN3 and AGPAT6 gene polymorphisms on milk production traits. Saanen goats were genotyped for milk traits, and the samples were collected during the lactation, and the milk yield/compositions of each goat were specified. In terms of the CSN3 and AGPAT6 genes, the genotypes were defined by PCR-RFLP. The milk yield (MY), lactation length (LL), protein, fat, total solid (TS), solid not fat (SNF), casein, lactose rates and yields were as follows; $388.9 \pm 17.5 \mathrm{~kg}, 243 \pm 5.81$ days, $3.29 \pm 0.05 \%, 3.59 \pm 0.07 \%, 11.60 \pm 0.13 \%, 8.43 \pm 0.06 \%, 2.57$ $\pm 0.04 \%, 4.31 \pm 0.03 \%, 11.21 \pm 0.47 \mathrm{~kg}, 12.79 \pm 0.64 \mathrm{~kg}, 40.95 \pm 1.82 \mathrm{~kg}, 29.53 \pm 1.31 \mathrm{~kg}, 8.82 \pm 0.37 \mathrm{~kg}, 15.40 \pm$ $0.74 \mathrm{~kg}$ respectively. The determined genotype and allele frequencies of CSN3 and AGPAT6 gene were as follows; FF (\%99.20), MF (\%0.80), F (0.996), M (0.004); GG (\%12), GC (\%43.20), CC (\%44.80), G (0.336), C (0.664). The impacts of lactation length on all milk yield parameters (protein, fat, TS, SNF, casein, lactose, MY) $(\mathrm{P}<0.001)$; the age on all milk yield parameters $(\mathrm{P}<0.001)$ and the protein, fat, SNF, casein rates $(\mathrm{P}<0.05)$, the TS rate and LL $(\mathrm{P}<0.01)$ were found to be significant. The birth type was not found to significantly affect any milk yield parameters. Although Saanen goats showed the variation for the AGPAT6 gene (g.9263C $>\mathrm{G}$ ), the herd was found to be monomorphic (FF) for the CSN3 gene. The effect of the AGPAT6 gene on milk traits in Saanen goats was determined not to be statistically significant. Environmental factors, such as maternal age and lactation length, were found to significantly affect some milk traits in Saanen goats. So consideration of factors such as maternal age or lactation length could be useful for improving breeding strategies for dairy goats.
\end{abstract}

Key words: milk yield/composition; PCR-RFLP; Saanen goats; CSN3; AGPAT6

\section{Introduction}

Goat products such as milk are some of the important factors contributing to the economy of farmers living in developing countries (BOSEWELL et al., 2018). In recent years, interest in goat's milk products has also increased in developed countries in Europe and America (SELVAGGI et al., 2014). This increase may be

associated with economic value due to the high prices of dairy products, as well as their beneficial ingredients (SELVAGGI et al., 2014).

The average milk yield of Saanen goats ranges from 204-1095 kg per lactation (BOICHARD et al., 1989; BELICHON et al., 1998; TZIBOULACLARKE, 2003; DAMIAN et al., 2008; TORRES-

\footnotetext{
*Corresponding author:

Research assist. Deniz Dincel, Phd., Department of Genetics, Faculty of Veterinary Medicine, Bursa Uludag University, Phone number: +90224 294 1335, Fax: +90 224294 1202; E-mail: deniz@uludag.edu.tr
} 
VÁZQUEZ et al., 2009; KESENKAS et al., 2010; TOLU et al., 2010; ULUTAS et al., 2010; NORRIS et al., 2011; BOLACALI and KUCUK, 2012; AKTAS et al., 2012; ISHAG et al., 2012). Similarly, like milk yield, it was noticed that the composition of milk varies between herds. Although the protein content of milk, which influences its cheese-making properties and is an important factor for the dairy industry, was reported as $2.84 \%$ in Saanen goats by DAMIAN at al. (2008). This ratio was estimated as $3.56 \%$ by NORRIS et al. (2011). The milk yield and composition are known to be affected by environmental factors, such as: breed (KOMINAKIS et al., 2000; GOETSCH et al., 2011), year (HAMED et al., 2009; KOMINAKIS et al., 2000; OLECHNOWICZ and SOBEK, 2008), season (GOETSCH et al., 2011; HAMED et al., 2009; CIAPPESONI et al., 2004), parIty (HAMED et al., 2009; KOMINAKIS et al., 2000; GOETSCH et al., 2011; OLECHNOWICZ and SOBEK, 2008; CIAPPESONI et al., 2004), and birth type (HAMED et al., 2009; KOMINAKIS et al., 2000; GOETSCH et al., 2011; OLECHNOWICZ and SOBEK, 2008; CIAPPESONI et al., 2004; GOONEWARDANE et al., 1999; KETTO et al., 2014). These factors were investigated in Zaraibi goats (HAMED et al., 2009), Skopelos goats (KOMINAKIS et al., 2000), Polish White improved goats (OLECHNOWICZ and SOBEK, 2008), Czech White Shorthaired goats (CIAPPESONI et al., 2004), Nubian goats (GOONEWARDANE et al., 1999), Norwegian $\mathrm{x}$ Small East crossbreds (KETTO et al.,2014) and Alpine goats (CREPALDI et al., 1999).

In Saanen goats, few studies have been performed about the effects of environmental factors such as season, year, age, lactation stage/length or parity on milk production traits (ISHAG et al., 2012; TORRES-VÁZQUEZ et al., 2009; ZOA-MBOÉ et al., 1997; NORRIS et al., 2011; MIOČ et al. 2008). Also, the results of the investigated effects differ from each other. In contrast to MIOČ et al. (2008), ISHAG et al. (2012), and NORRIS et al. (2011), the effect of age on MY, fat, and protein percentage was found to be significant by ZOAMBOÉ et al. (1997) and TORRES-VÁZQUEZ et al. (2009). On the other hand, the effect of birth type on lactation traits in Saanen goats has only been investigated by BOLACALI and KUCUK (2012). Furthermore, the effect of lactation length on these traits has only been analyzed by ISHAG et al. (2012).

The $\kappa$-casein gene $(C S N 3)$ located on caprine chromosome 6 contains five exons, and most of the coding sequences of the mature protein (162 aa) are present in exon 4 (YAHYAOUI et al. 2001; 2003). (Gene ID:100861231). The polymorphism of the caprine CSN3 gene that substitutes Val119 to Ile119 was first reported by MERCIER et al. (1976). The gene was extremely polymorphic with 21 identified alleles (A, B, B', B", C, C', D, E, F, G, H, I, J, K, L, M, N, O, P, Q, and R; PRINZENBERG et al., 1999 and 2005; CAROLI et al., 2001; YAHYAOUI et al., 2001; JANN et al., 2004; GUPTA et al., 2009). All these variants are separated into two groups; $\operatorname{AIEF}(A, B, B$ ', B', C, C', F, G, H, I, J, L) and BIEF (D, E, K, M, N, O, P, Q, R) according to isoelectric points (PRINZENBERG et al., 2005). CHIANESE et al. (2000) reported that the BIEF group of CSN3 variants might be related to the high casein content in milk. The effect of the CSN3 gene on protein and casein contents was studied in Murciano-Granadina goats (CARAVACA et al., 2009); Camosciata, Frisa, Orobico, Verzasca goats (CHIATTI et al., 2007); and Norwegian dairy goats (DAGNACHEW et al., 2011). According to the results obtained, the effects of the investigated alleles were found to be statistically significant. Similar to the previous studies, SZTANKÓOVÁ et al. (2009) indicated that the alleles of B, C, and $\mathrm{D}$ of the CSN3 gene affected the protein content of Czech dairy goats milk. However, polymorphisms or effects of the CSN3 gene have been investigated in various goat breeds, while studies on Saanen goats are limited. Moreover, the $\mathrm{F}$ and $\mathrm{M}$ alleles of the CNS3 gene were not studied sufficiently, while predominantly the alleles of $\mathrm{A}$ and $\mathrm{B}$ were investigated. PRINZENBERG et al. (2005) studied the existence of CSN3*M (Gen Bank accession no: AY428577) and *F (Gen Bank accession no: AY090466) alleles in Saanen goats. The $\mathrm{M}$ allele of the CSN3 gene differs from two nonsynonymous mutations $(\mathrm{G} \rightarrow \mathrm{A}$ transition at position 384, resulted in Asp90 $\rightarrow$ Asn90 amino acid changes; $\mathrm{C} \rightarrow \mathrm{T}$ transition at position 550 resulted in 
Val145 $\rightarrow$ Ala145 amino acid changes) from the $F$ allele (PRINZENBERG et al., 2005).

The AGPAT enzyme family contained in Lysophosphatidic acid acyltransferase (LPAAT) has eight members, known as AGPAT1, 2, 3, 4, 5, 6, 7, and 8 (YE et al., 2005). The AGPAT6 gene (also known as GPAT4) located on caprine chromosome 27, has 14 exons (Gen Bank ID. NC_022319.1). BEIGNEUX et al. (2006) indicated that AGPAT6, used in triglyceride biosynthesis, is expressed in the epithelial breast tissue in mice. The milk of mice had AGPAT6 -/- genotype, and was found to be free of diacylglycerol and triacylglycerol; the breast epithelium did not develop, and it was noticed that intracellular fat droplets were smaller in those animals (BEIGNEUX et al., 2006). As a result, it was concluded that the AGPAT6 gene plays a key role in milk fat production in the breast epithelium. BIONAZ and LOOR (2008) emphasized that AGPAT6 affected the fat content of milk by regulating the fat synthesis in the Holstein breed. The g. $9263 \mathrm{C}>\mathrm{G}$ mutation occurred in the $4^{\text {th }}$ exon of the AGPAT6 gene, resulting in a synonymous genetic code with threonine "ACC(Thr) $>$ ACG(Thr)" at position 195 aa of AGPAT6 (HE et al., 2011). They reported that the frequencies of $\mathrm{CC}, \mathrm{GC}$, and $\mathrm{GG}$ genotypes were $0.694,0.198$, and 0.108 g.9263C $>\mathrm{G}$ mutation in Xinong Saanen ve Guanzhong goats. According to that study, the milk fat/protein content and milk yields varied depending on $\mathrm{CC}, \mathrm{GC}$, and GG genotypes, and individuals with GG and GC genotypes had significantly higher milk yield and composition. On the otherhand, the significanteffects of the AGPAT6 gene on milk protein composition were studied by MIKAILAITE் (2017), and it was claimed that individual Lithuanian dairy goats that had CG genotype (g.9263C $>\mathrm{G}$ ) produced higher milk protein yield. However, studies of AGPAT6 gene polymorphisms are limited in the literature.

Besides the limited data on candidate genes' (such as CSN3 and AGPAT6) effects on milk yield and composition in Saanen goats, to the best of our knowledge, the wide range studies about milk traits, including milk SNF, lactose, or casein yields of Saanen goats are insufficient. Thus, this study aimed to determine the effects of some environmental factors such as age, lactation length, and birth type on the milk yield and composition of Saanen goats. Another objective of the current study was to estimate the frequencies of CSN3 $(550 \mathrm{C} \rightarrow \mathrm{T})$ and AGPAT6 (g.9263C $>\mathrm{G}$ ) gene polymorphisms in Saanen goats and their effects on milk yield and composition.

\section{Materials and methods}

Animals. The data were obtained from Saanen goats $(\mathrm{n}=125)$ in the Southern Marmara Region of Turkey. The goats belonged to two independent herds (Farm1 and Farm 2) located in Bursa, Turkey. The latitude and longitude of Farm 1 (Herd1) and Farm 2 (Herd2) are $40^{\circ} 13^{\prime} 51.5^{\prime \prime} \mathrm{N} 28^{\circ} 52^{\prime} 31.0^{\prime \prime} \mathrm{E}$ and $40^{\circ} 02^{\prime} 47.5^{\prime \prime} \mathrm{N} 28^{\circ} 51^{\prime} 44.4 " \mathrm{E}$ respectively. The goats were selected randomly within the herds, were genetically different from each other, and reared intensively. A commercial concentrated feed (2500 $\mathrm{kcal} / \mathrm{kg}$ ) and dried clover were used ad libitum for consumption by the Saanen does. The goats $(\mathrm{n}=$ $125)$ were investigated for genetic parameters such as the CSN3 and AGPAT6 gene. Moreover, some of them were screened for milk traits during the lactation period. For all procedures, ethical approval was received (2012-04/03).

Milk traits. Saanen does were milked by machine twice a day. The milk data, including the yields and components [protein, fat, total solid (TS), solid not fat (SNF), casein, lactose, and total MY], were recorded throughout lactation from Saanen goats from Herd 1 (in 2012). During lactation, milk samples were collected in $100 \mathrm{~mL}$ sterile sample containers twice a month. Samples were transported to the laboratory via a cold chain $\left(+4{ }^{\circ} \mathrm{C}\right)$ within two hours. The total MY of lactation per animal was evaluated by the Fleischmann method (Trapez II), according to the International Committee for Animal Recording (ICAR) Guidelines 2014 (BERGER and THOMAS, 2005). The samples were analyzed for milk contents, such as total protein, fat, TS, SNF, total casein, and lactose by Fourier transform infrared (FTIR) spectroscopy (MilkoScan ${ }^{\mathrm{TM}}$ FT1, Foss Electric, Hillerød, Denmark) (BERGE et al., 2010).

CSN3 and AGPAT6 gene analysis. Blood samples were collected aseptically from the jugular vein in EDTA. All samples were transported to the laboratory at low temperature, and were kept at -20 ${ }^{\circ} \mathrm{C}$ until DNA extraction at the genetic laboratory 
of the Faculty of Veterinary Medicine, Uludag University. The genomic DNA was extracted by the phenol-chloroform method according to POWELL and GANNON (2002). The characteristics of the DNA, the purity and amount, were determined by spectrophotometer according to the ratio of absorbance at 260 and $280 \mathrm{~nm}(260 / 280)$ (Thermo/ NanoDrop 2000C). The extracted DNA samples were stored at $-80{ }^{\circ} \mathrm{C}$ until the PCR-RFLP was performed. The polymorphisms of CSN3 (550 $\mathrm{C} \rightarrow \mathrm{T}$ ) and AGPAT6 (g.9263C $>\mathrm{G}$ ) were determined by the PCR-RFLP method, according to CHESSA et al. (2003), PRINZENBERG et al. (2005), and HE et al. (2011) respectively. The 407 bp PCR product for CNS3 and $241 \mathrm{bp}$ PCR products for the AGPAT6 gene were amplified using the established primer sets and conditions given in Table 1 .

Table 1. Primer sets and PCR conditions of CSN3 and AGPAT6 gene

\begin{tabular}{|c|c|c|c|c|}
\hline Gene & Primer sets & $\begin{array}{l}\text { Product } \\
\text { size }\end{array}$ & PCR conditions & References \\
\hline $\begin{array}{l}C S N 3- \\
550 \mathrm{C} \rightarrow \mathrm{T}\end{array}$ & $\begin{array}{l}\text { KCNI-F: GGTATCCTAGTTATGGACT- } \\
\text { CAAT } \\
\text { KCN I-R: } \\
\text { GTTGAAGTAACTTGGGCTGTGT }\end{array}$ & $407 \mathrm{bp}$ & $\begin{array}{l}94^{\circ} \mathrm{C} 1,5 \mathrm{~m} \\
{\left[94^{\circ} \mathrm{C} 45 \mathrm{~s}\right.} \\
56,5^{\circ} \mathrm{C} 45 \mathrm{~s} \\
\left.72^{\circ} \mathrm{C} \cdot 45 \mathrm{~s}\right] \times 35 \text { cycle } \\
72^{\circ} \mathrm{C} 5 \mathrm{~m}\end{array}$ & $\begin{array}{l}\text { Chessa et al. 2003, } \\
\text { Prinzenberg et al., } \\
2005\end{array}$ \\
\hline $\begin{array}{l}\text { AGPAT6- } \\
\text { g. } 9263 \mathrm{C}>\mathrm{G}\end{array}$ & $\begin{array}{l}\text { F: ATCTGGCATTTTCACACATT } \\
\text { R: CTGACTCCATCTAAGAGCCT }\end{array}$ & $241 \mathrm{bp}$ & $\begin{array}{l}95^{\circ} \mathrm{C} 5 \mathrm{~m} \\
{\left[94^{\circ} \mathrm{C} 30 \mathrm{~s}\right.} \\
53^{\circ} \mathrm{C} 30 \mathrm{~s} \\
\left.72^{\circ} \mathrm{C} 35 \mathrm{~s}\right] \times 34 \text { cycle } \\
72^{\circ} \mathrm{C} 10 \mathrm{~m}\end{array}$ & He et al., 2011 \\
\hline
\end{tabular}

PCR products were evaluated by electrophoresis on $2-2.5 \%$ agarose gel. Differentiation between the $\mathrm{M}$ and $\mathrm{F}$ alleles of the CSN3 gene and the $\mathrm{G}$ and $\mathrm{C}$ alleles of the AGPAT6 gene was performed by RFLP analysis. A $5 \mu \mathrm{L}$ of each PCR product was digested with PstI and NcoI-HF restriction enzyme for the CSN3 and AGPAT6 genes, respectively, at $37^{\circ} \mathrm{C}$ for about 16 hours, according to the manuals. The enzyme products were estimated by $3 \%$ agarose gel electrophoresis (COSENZA et al., 2008). The bands of PCR and enzyme products were visualized using the DNr Minilumi imaging system.

Statistical analyses. Popgene v1.32 software was used for calculation of the genotype frequencies of CSN3 and AGPAT6 gene. Data were processed by the software to estimate the genotype frequencies and possible deviation from the Hardy-Weinberg equilibrium of Saanen goats (YEH et al., 2000). Statistical analysis of milk yield/composition was carried out by the Minitab 15 statistical software (Minitab Inc., 2000) using the general linear model procedure (GLM) with the following model for milk composition:
$\mathrm{Y}_{\mathrm{ijk}}=\mu+\mathrm{C}_{\mathrm{i}}+\mathrm{D}_{\mathrm{j}}+\mathrm{E}_{\mathrm{k}}+\mathrm{e}_{\mathrm{ijk}}$

$Y_{i j k}=$ the dependent variable (LL, protein, fat, TS, SNF, casein and lactose rate);

$\mu=$ the overall mean;

$C_{i}=$ the fixed effect of $A G P A T 6$ gene $(\mathrm{g} .9263 \mathrm{C}>\mathrm{G})(\mathrm{i}=$ $\mathrm{CC}, \mathrm{GC}, \mathrm{GG})$;

$D_{j}=$ the fixed effect of does age $(\mathrm{k}=1,2,3,4 \geq$ age $)$;

$E_{k}=$ the fixed effect of birth type $(\mathrm{j}=$ single, twin, triplet $)$;

$e_{i j k l}=$ the random error.

The model for protein, fat, TS, SNF, casein, lactose and lactation $\mathrm{MY}$ is as follows:

$\mathrm{Y}_{i j k l}=\mu+\mathrm{C}_{\mathrm{i}}+\mathrm{D}_{\mathrm{j}}+\mathrm{E}_{\mathrm{k}}+\mathrm{F}_{1}+\mathrm{e}_{i j k l}$

$Y_{i j k}=$ the dependent variable (protein, fat, TS, SNF, casein, lactose and lactation MY);

$\mu=$ the overall mean;

$C_{i}=$ the fixed effect of $A G P A T 6$ gene $(\mathrm{g} .9263 \mathrm{C}>\mathrm{G})(\mathrm{i}=$ $\mathrm{CC}, \mathrm{GC}, \mathrm{GG}$ );

$D_{i}=$ the fixed effect of does age $(\mathrm{j}=1,2,3,4 \geq$ age $)$;

$E_{k}^{J}=$ the fixed effect of birth type $(\mathrm{k}=$ single, twin, triplet);

$F_{l}==$ the fixed effect of lactation length period $(1=$ 1:180-210 day, 2:211-230 day, 3:231-250 day, 4:251270 day, 5:271-288 day);

$e_{i j k l}=$ the random error. 


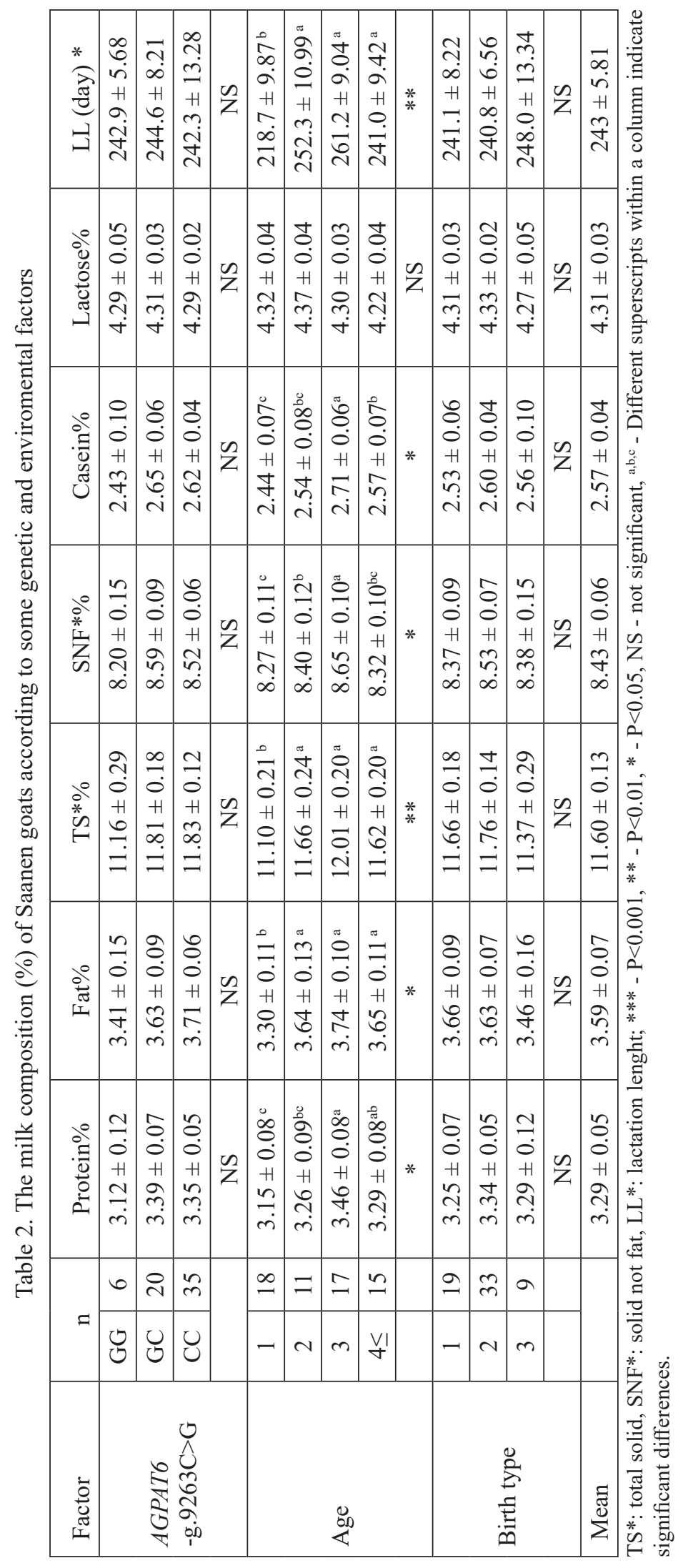




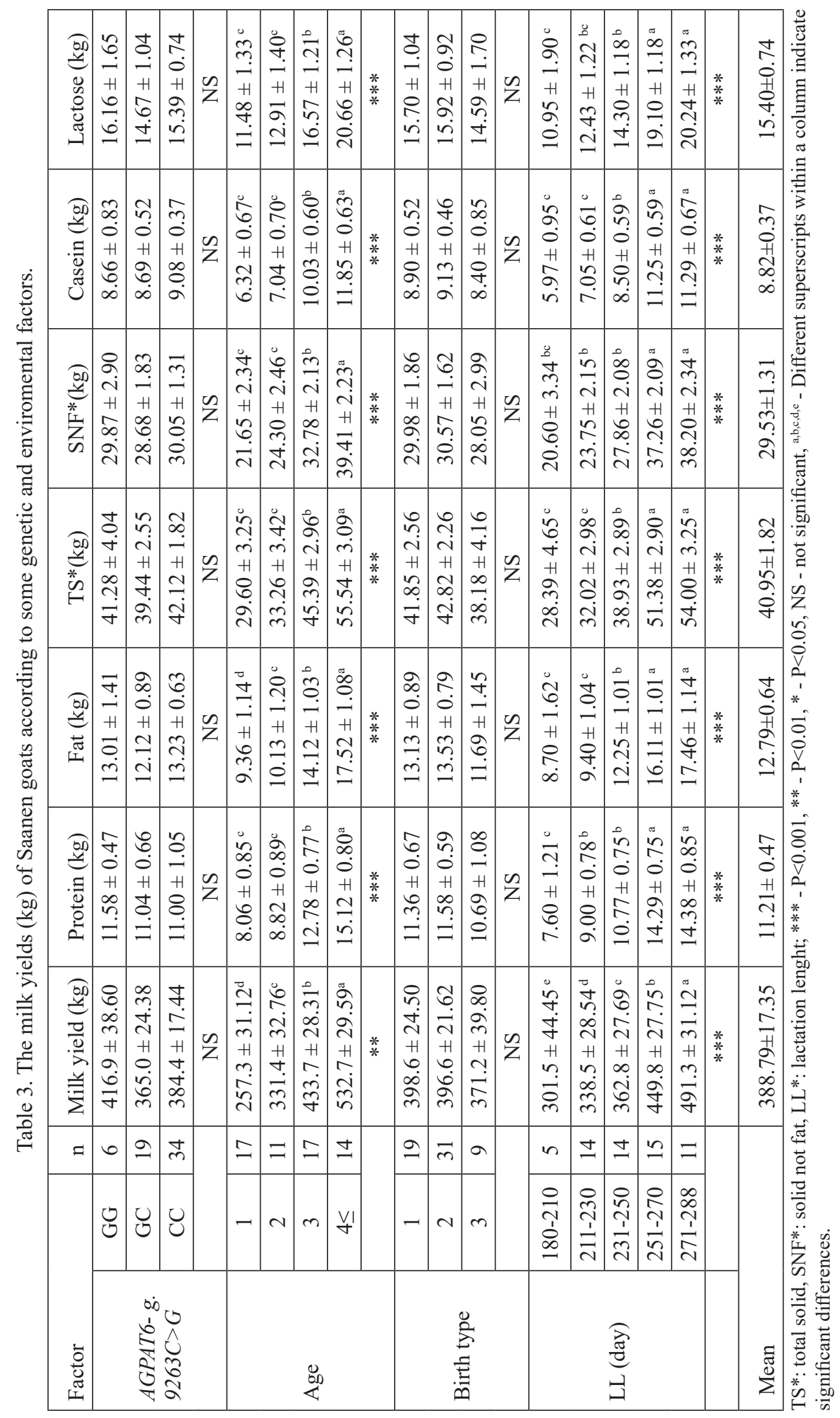



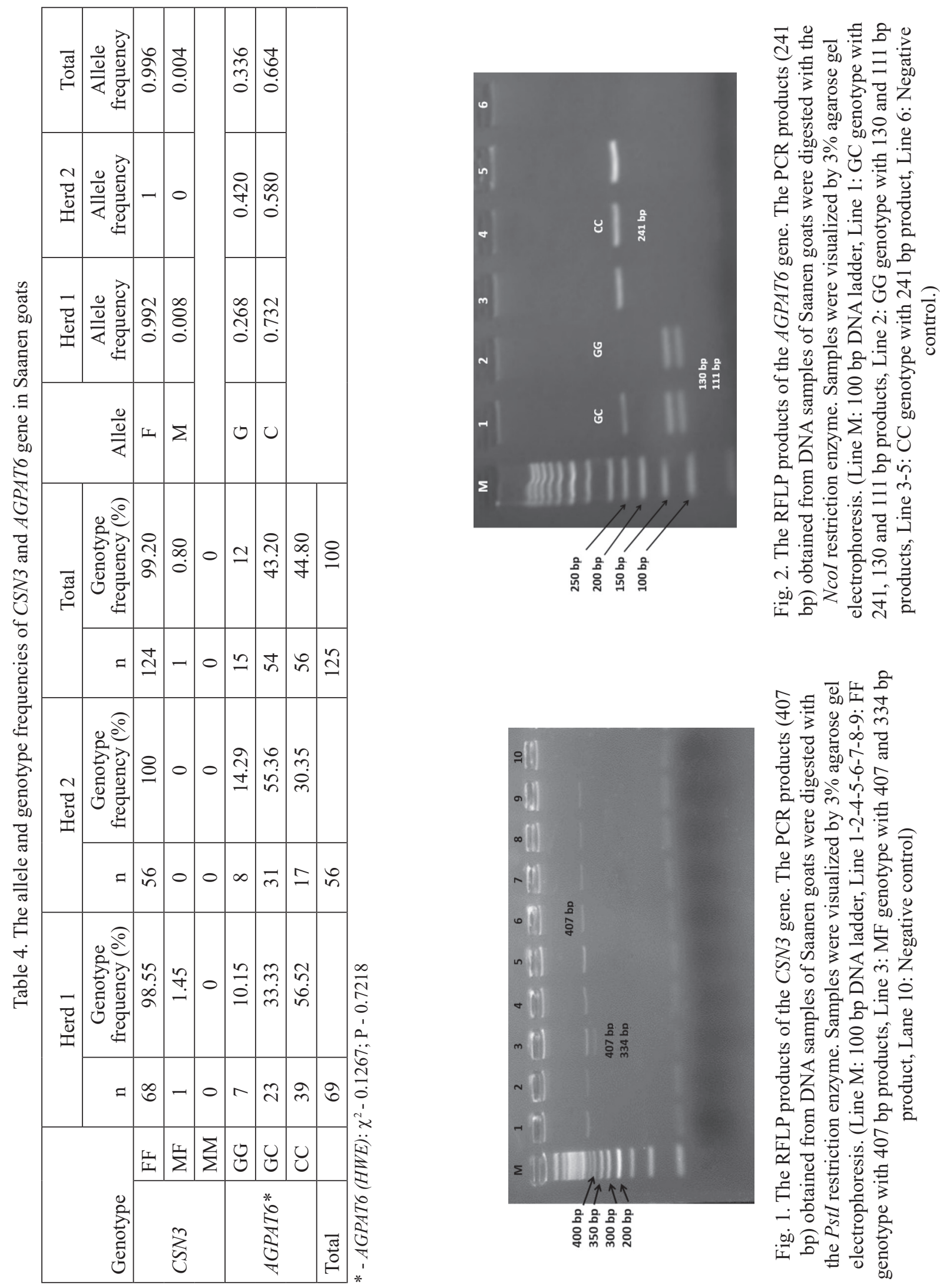


\section{Results}

Milk traits. According to the results; LL, protein, fat, TS, SNF, casein, lactose rates were; $243 \pm 5.81$ days, $3.29 \pm 0.05 \%, 3.59 \pm 0.07 \%, 11.60 \pm 0.13 \%$, $8.43 \pm 0.06 \%, 2.57 \pm 0.04 \%, 4.31 \pm 0.03 \%$ (Table 2) respectively. Moreover, the mean yield of total milk, protein, fat, TS, SNF, casein and lactose were determined as; $388.9 \pm 17.5 \mathrm{~kg}, 11.21 \pm 0.47 \mathrm{~kg}, 12.79$ $\pm 0.64 \mathrm{~kg}, 40.95 \pm 1.82 \mathrm{~kg}, 29.53 \pm 1.31 \mathrm{~kg}, 8.82 \pm$ $0.37 \mathrm{~kg}, 15.40 \pm 0.74 \mathrm{~kg}$, respectively (Table 3 ). The impact of age on all MY parameters (protein, fat, total solid, solid not fat, casein, and lactose yield) $(\mathrm{P}<0.001)$ was found to be statistically significant. Furthermore, the percentages of milk components, such as protein $(\mathrm{P}<0.05)$, fat $(\mathrm{P}<0.05)$, TS $(\mathrm{P}<0.01)$, SNF $(\mathrm{P}<0.05)$, casein $(\mathrm{P}<0.05)$, and lactation length $(\mathrm{P}<0.01)$ were significantly affected by age. It was observed that the fat, TS, and LL increased with age, and the highest MY were determined in four year old does.

CSN3 and AGPAT6 gene. The genotype and allele frequencies of CSN3 and AGPAT6 gene were determined in Saanen goats. The PCR-RFLP results revealed that two different genotypes (FF and MF) were detected for the CNS3 gene (Fig. $1)$; the frequencies of the $\mathrm{FF}$ and MF genotype for $550 \mathrm{C} \rightarrow \mathrm{C}$ SNP were $99.20 \%$ and $0.80 \%$, respectively (Table 4). Also, the allele frequencies of $F$ and $M$ were 0.996 and 0.004 . Since only one individual had a heterozygote genotype (MF), the herds were identified as monomorphic (FF) for the CSN3 gene. Therefore the effect of the CSN3 gene on milk yield and composition was not estimated. For the AGPAT6 gene, three different genotypes (GG, GC, CC) were observed, as shown in Fig. 2. The following genotype frequencies of AGPAT6 (g.9263C $>\mathrm{G}$ ) were determined respectively: GG $(12.00 \%)$, GC $(43.20 \%), \mathrm{CC}(44.80 \%)$ with the allele frequencies $\mathrm{G}(0.336)$ and $\mathrm{C}(0.664)$. The most frequent genotype was CC for the AGPAT6 gene in the investigated Saanen flock. The effect of the AGPAT6 gene on the investigated milk traits was determined not to be statistically significant in Saanen goats in the current study.

\section{Discussion}

Milk traits. Accordingly to the literature, there is high variability in the recorded lactation MY of Saanen goats. The result regarding the MY obtained in this study was lower than those reported by BOICHARD et al. (1989), BELICHON et al. (1998), TORRES-VÁZQUEZ et al. (2009), TOLU et al. (2010), and VLAD et al. (2014), but higher than those determined by ULUTAS et al. (2010), BOLACALI and KUCUK, 2012, AKTAS et al. (2012) and ISHAG et al. (2012). In common with MY, the LL also differs throughout the literature. the LL in the present study $(243 \pm 5.81)$ was detected to be lower than that reported by TOLU et al. (2010), BOLACALI and KUCUK (2012). However, this parameter was found to be higher than that reported by BOICHARD et al. (1989), ULUTAS et al. (2010), AKTAS et al. (2012), ISHAG et al. (2012), and VLAD et al. (2014). The difference between LL values might originate from the distinction of milk yields depending on nutritional levels affected by the climatic conditions of the breeding area or differences in genotypic structure.

Contrary to ZOA-MBOÉ et al. (1997), the findings of the present study were in agreement with those reported by TORRES-VÁZQUEZ et al., (2009), ZOA-MBOÉ et al. (1997), and BOLACALI and KUCUK (2012). ZOA-MBOÉ et al. (1997) indicating that the factor of age influenced all milk, fat, and protein yield/composition traits, except the fat percentage. The impact of age on lactation traits might be explained by the developing udder structure due to the increase in body size with age. Hence milk production capacity improves with advanced age. In close agreement with ISHAG et al. (2012), the effect of lactation length on all MY parameters (lactation milk, protein, fat, total solid, solid not fat, casein, and lactose yield $)(\mathrm{P}<0.001)$ were defined as statistically significant. The peak MY's were identified in does with 251-270 and 271-288 days of LL. In this study, no significant differences were observed due to the effects of birth type on milk production traits $(\mathrm{P}>0.05)$. These observations differ from the work of BOLACALI and KUCUK (2012), ISHAG et al. (2012), who determined that the effect of birth type on total milk yield was significant. 
CSN3 and AGPAT6 genes. The A and $\mathrm{B}$ alleles of the CSN3 gene have been studied in various goat breeds, including Saanen goats (YAHYAOUI et al., 2001/2003; PRINZENBERG et al., 2005; KUMAR et al., 2009; CHIATTI et al., 2007; CARAVACA et al. 2009; SZTANKÓOVÁ et al., 2009; GUPTA et al., 2009; CAROLI et al., 2001 and STRZELEC and NIŻNIKOWSKI, 2011; CHESSA et al., 2003). The frequencies of the M and $\mathrm{F}$ alleles of the CSN3 gene were investigated in the current study, and the results showed that the genotype frequencies were $99.20 \%$ for $\mathrm{FF}$ and $0.80 \%$ for MF in the Saanen breed. These findings were partially compatible with the work of PRINZENBERG et al. (2005), who reported that the frequencies of $\mathrm{M}$ allele were null. Only one individual was identified as a heterozygote (MF), as shown in Fig. 1. In another study, performed for the same SNP by STRZELEC and NIŻNIKOWSKI (2011), the "a" and "g" alleles were identified (the "a" allele accepted to B variant of CSN3 gene) and "aa" and "gg" genotype frequencies were determined as $78.13 \%$ and $21.88 \%$ in the Saanen breed. However, these results were not similar to our data because the frequency of the B variant ("aa"), which is known to contain the $\mathrm{M}$ allele, was found to be dominant in that study in contrast to the present study. The observed variation in genotype frequencies could be explained by the differences in genetic structure. Since the herd was found to be monomorphic for CSN3 gene polymorphism (550 $\mathrm{C} \rightarrow \mathrm{T}$ ), this effect on milk traits was not evaluated.

The genotypic frequencies of the AGPAT6 gene were similar to data recorded by MIKAILAITE (2017), who reported that the frequencies were $42.9 \%, 42.9 \%$, and $14.2 \%$ for $\mathrm{CC}, \mathrm{GC}$, and $\mathrm{GG}$ genotypes, respectively. These findings are in agreement with those reported by HE et al. (2011). The genotype frequencies were established to be $10.8 \%$ for CC, $19.8 \%$ for GC, and $69.4 \%$ for GG. Also, the allele frequencies of the AGPAT6 gene for g. $9263 \mathrm{C}>\mathrm{G}$ polymorphism were 0.793 and 0.207 for $\mathrm{G}$ and $\mathrm{C}$. Therefore, our results of allele frequencies (G:0.336, C:0.664) conflict with the work of HE et al. (2011). This might be due to the variation in the genetic structure in the investigated goats that had different origins. HE et al. (2011) emphasized that individuals with GG and GC genotypes had higher milk fat and protein percentages, as well as milk yield, compared to those of the CC genotype, in addition to the genotype/allele frequencies of the gene. Unlike the findings of HE et al. (2011), the effect of the AGPAT6 gene on milk traits was determined as insignificant in this study. Moreover, these results were not similar to data indicated by MIKAILAITE (2017), who claimed that goats with the GC genotype had higher protein content than the others. The reason for the differences in the effects on milk traits compared to previous studies could be explained by flock differences or the sample size of the study. The significant effects of the AGPAT6 gene for g. $9263 \mathrm{C}>\mathrm{G}$ on milk traits, especially milk fat content, could be the result of the larger amount of phenotypic or genotypic data.

\section{Conclusions}

In conclusion, the effect of some environmental factors on milk yield and composition and the effect of CSN3 and AGPAT6 gene polymorphisms on milk production traits in Saanen goats were established. Parameters such as SNF, lactose, or casein yield of Saanen milk, which are important factors for the dairy industry, were first reported in this study. Environmental factors, such as maternal age and lactation length, were found to be significant for milk production traits in Saanen goats. So, consideration of these environmental factors, which were found to be statistically significant in the present study, could be useful as selection criteria in dairy goat breeding for higher milk yield and better composition. Furthermore, screening of the other regions of the CSN3, AGPAT6 genes, and also the investigation of the phenotypic association between them could be useful in order to clarify the efficiency of target genes.

\section{Acknowledgment}

The authors would like to thank the CAPRA goat breeding company for their help in managing the animals and collecting blood samples. This study was supported by "Uludag University Scientific Research Projects Unit" with the project number of OUAP(V)-2012/18. 
D. Dincel et al.: Evaluation of some environmental and genetic factors (CSN3 and AGPAT6 gene) on milk yield and composition in Saanen goats

\section{References}

AKTAS, Z. M., A. KAYGISIZ, S. BAS (2012): Relationships between Turkish Saanen goats milk yield characteristics, some udder sizes and somatic cell score (SCC) in Kahramanmaras breeder conditions. KSU J. Nat. Sci. 15, 7-17 (in Turkish).

BEIGNEUX, A. P., L. VERGNES, X. QIAO, S. QUATELA, R. DAVIS, S. M. WATKINS, R. A. COLEMAN, R. L. WALZEM, M. PHILIPS, K. REUE, S. G. YOUNG (2006): Agpat6-a Novel lipid biosynthetic gene required for triacylglycerol production in mammary epithelium. J. Lipid Res. 47, 734-744.

DOI: 10.1194/jlr.M500556-JLR200

BÉLICHON, S., E. MANFREDI, A. PIACÈRE (1998): Genetic parameters of dairy traits in the Alpine and Saanen goat breeds. Genet. Sel. Evol. 30, 529-534.

DOI: 10.1186/1297-9686-31-5-529

BERGER, Y. M., D. L. THOMAS (2005): Milk testing, calculation of milk production and adjustment factors. Proceedings of $10^{\text {th }}$ Great Lakes Dairy Sheep Symposium, 4-6 November, Hudson, Wisconsin, USA, pp. 55-63.

BERGE, T. I., H. MARTENS, A. KOHLER, S. K. SJURSETH, N. K. AFSETH, B. NARUMN, T. ÅDNØY, S. LIEN (2010): Caprine CSN1S1 haplotype effect on gene expression and milk composition measured by Fourier transform infrared spectroscopy. J. Dairy Sci. 93, 4340-4350.

DOI: $10.3168 /$ jds.2009-2854

BIONAZ, M., J. J. LOOR (2008): ACSL1, AGPAT6, FABP3, LPIN1, and SLC27A6 are the most abundant 1soforms in bovine mammary tissue and their expression is affected by stage of lactation. J. Nutr. 138, 1019-1024.

DOI: $10.1093 / \mathrm{jn} / 138.6 .1019$

BOICHARD, D., N. BOULOC, G. RICORDEA, A. PIACERE, F. BARILLET (1989): Genetic parameters for first lactation dairy traits in the Alpine and Saanen goat breeds. Genet. Sel. Evol. 21, 205-215.

DOI: $10.1186 / 1297-9686-21-2-205$

BOLACALI, M., M. KUCUK (2012): Fertility and milk production characteristics of Saanen goats raised in Muş region. Kafkas Univ. Vet. Fak. Derg, 18, 351-358.

DOI: $10.9775 / \mathrm{kvfd} .2011 .4895$

BOSEWELL, A., T. NAICY, T. V. ARAVINDAKSHAN, E. KURIAN (2018): Sequence characterization, structural analysis, SNP detection and expression profiling of SLC11A1 gene in Indian goats, Small Rumin. Res. 164, 15-21.

DOI: 10.1016/j.smallrumres.2018.04.012

CARAVACA, F., J. CARRIZOSA, B. URRUTIA, F. BAENA, J. JORDANA, M. AMILLS, B. BADAOUI, A. SÁNCHEZ, A. ANGIOLILLO, J. M. SERRADILLA (2009): Short communication: Effect of $\alpha \mathrm{S} 1$-casein (CSN1S1) and $\kappa$-casein (CSN3) genotypes on milk composition in Murciano-Granadina goats. J. Dairy Res. 92, 2960-2964. DOI: $10.1017 /$ S002202991000083X
CAROLI, A., O. JANN, E. BUDELLUI, P. BOLLA, S. JAGÈR, G. ERHARDT (2001): Genetic polymorphism of goat $\mathrm{k}$-casein $(C S N 3)$ in different breeds and characterization at DNA level. Anim. Genet. 32, 226-230.

DOI: $10.1046 / j .1365-2052.2001 .00765 . x$

CHESSA, S., E. BUDELLI, K. GUTSCHER, A. CAROLI, G. ERHARDT (2003): Short Communication: Simultaneous identification of five $\kappa$-casein (CSN3) alleles in domestic goat by polymerase chain reaction-single strand conformation polymorphism. J. Dairy Sci. 86, 3726-3729. DOI: 10.3168/jds.S0022-0302(03)73978-2

CHIANESE, L., B. PORTOLANO, E. TRONCONE, F. PIZZOLONGO, P. FERRANTI, F. ADDEO, M. L. ALICATA, F. PILLA, G. CALCAGNA (2000): The quality of Girgentana goat milk. Proceedings $7^{\text {th }}$ International Conference on Goats, 15-18 May, Tour, France, pp. 946949.

ChiATti, F., S. CHESSA, P. BOLla, A. Cigalino, A. CAROLI, G. PAGNACCO (2007): Effect of $\kappa$-Casein polymorphism on milk composition in the Orobica goat. J. Dairy Sci. 90, 1962-1966.

DOI: $10.3168 /$ jds.2006-508

CIAPPESONI, G., J. PRIBLY, M. MILERSKI, V. MARES (2004): Factors affecting goat milk yield and its composition. Czech J. Anim. Sci. 49, 465-473.

DOI: $10.17221 / 4333$-cjas

COSENZA, G., A. PAUCIULLO, D. GALLO, L. COLIMORO, A. D'AVINO, A. MANCUSI, L. RAMUNNO (2008): Genotyping at the CSN1S1 locus by PCR-RFLP and ASPCR in a Neapolitan goat population. Small Rumin. Res. 74, 84-90.

DOI: 10.1016/j.smallrumres.2007.03.010

CREPALDI, P., M. CORTI, M. CICOGNA (1999): Factors affecting milk production and prolificacy of Alpine goats in Lombardy (Italy). Small Rumin. Res. 32, 83-88.

DOI: 10.1016/S0921-4488(98)00156-4

DAGNACHEW, B. S., G. THALLER, S. LIEN, T. ÅDNØY (2011): Casein SNP in Norwegian goats: additive and dominance effects on milk composition and quality. Genet. Sel. Evol. 43, 31.

DOI: $10.1186 / 1297-9686-43-31$

DAMIÁN, J. P., I. SACCHI, S. REGINENSI, D. D. LIMA, J. BERMÛDEZ (2008): Cheese yield, casein fraction and major components of milk of Saanen and Anglo-Nubian dairy goats. Arq. Bras. Med. Vet. Zootec. 60, 1564-1569.

DOI: 10.1590/S0102-09352008000600040

GOETSCH, A. L., S. S. ZENG, T. A. GIPSON (2011): Factors affecting goat milk production and quality. Small Rumin. Res. 101, 55-63.

DOI: 10.1016/j.smallrumres.2011.09.025 
D. Dincel et al.: Evaluation of some environmental and genetic factors (CSN3 and AGPAT6 gene) on milk yield and composition in Saanen goats

GOONEWARDENE, L. A., E. OKINEA, N. PATRICK, H. D. SCHEER (1999): The relationship between multiple births and milk yields in non-suckled intensively managed dairy goats. Small Rumin. Res. 32, 181-185.

DOI: 10.1016/S0921-4488(98)00179-5

GUPTA, S. C., D. KUMAR, A. PANDEY, G. MALIK, N. GUPTA (2009): New k-casein alleles in Jakhrana goat affecting milk processing properties. Food Biotechnol. 23, 83-96.

DOI: $10.1080 / 08905430802672079$

HAMED, A., M. M. MABROUK, I. SHAAT, S. BATA (2009): Estimation of genetic parameters and some non-genetic factors for litter size at birth and weaning and milk yield traits in Zaraibi Goats. EJSGS 4, 55-64.

DOI: $10.21608 /$ ejsgs.2009.27667

HE, C., C. WANG, Z. H. CHANG, B. L. GUO, R. LI, X. P. YUE, X. Y. LAN, H. CHEN, C. Z. LEI (2011): AGPAT6 polymorphism and its association with milk traits of dairy goats. Genet. Mol. Res. 10, 2747-2756.

DOI: $10.4238 / 2011$.November.4.8

ISHAG, I. A., S. A. ABDALLA, M. K. A. AHMED (2012): Factors affecting milk production traits of Saanen goat raised under Sudan - semi arid conditions. J. Anim. Feed Res. 1, 435-438.

JANN, O., E. M. PRINZENBERG, G. LUIKART, A. CAROLI, G. ERHARDT (2004): High polymorphism in the k-casein (CSN3) gene from wild and domestic caprine species revealed by DNA sequencing. J. Dairy Res. 71, 188-195. DOI: $10.1017 / \mathrm{s} 0022029904000093$

KESENKAS, H., N. O. DINKCI, S. GONC, G. ENDER (2010): General characteristics of Saanen goat milk. Academic Food Journal. 8, 45-48 (in Turkish).

KETTO, I. A., I. MASSAWE, G. C. KIFARO (2014): Effects of supplementation, birth type, age and stage of lactation on milk yield and composition of Norwegian x Small East African goats in Morogoro, Tanzania. Livestock Res. Rural Dev. 26, 234-256.

KOMINAKIS, A., E. ROGDAKISA, C. VASILOUDISB, O. LIASKOS (2000): Genetic and environmental sources of variation of milk yield of Skopelos dairy goats. Small Rumin. Res. 36, 1-5.

DOI: 10.1016/S0921-4488(99)00105-4

KUMAR, A., P. K. ROUT, A. MANDAL, R. ROY (2009): Kappa-Casein gene polymorphism in Indian goats. Indian J. Biotechnol. 8, 214-217.

MERCIER, J. C., F. ADDEO, J. P. PELISSIER (1976): Primary structure of the casein macropeptide of caprine kappa casein. Biochimie. 58, 1303-1310.

MIKAILAITEE, I. (2017): STAT5 and AGPAT6 genes polymorphism association with milk traits of dairy goat. Thesis, Lietuvos Sveikatos Mokslų Universitetas Veterinarijos Akademija, Kaunas, http://repository.lsmuni. lt/handle/1/33904.
MIOČ, B., Z. PRPIĆ, I. VNUČEC, Z. BARAĆ, V. SUŠIĆ, D. SAMARŽIJA, V. PAVIĆ (2008): Factors affecting goat milk yield and composition. Mljekarstvo 58, 305-313.

NORRIS, D., J. W. NGAMBI, K. BENYI, C. A. MBAIORGU (2011): Milk production of three exotic dairy goat genotypes in Limpopo Province, South Africa. Asian J. Anim. Vet. Adv. 6, 274-281.

DOI: 10.3923/ajava.2011.274.281

OLECHNOWICZ, J., Z. SOBEK (2008): Factors of variation influencing production level, SCC and basic milk composition in dairy goats. J. Anim. Feed Sci. 17, 41-49. DOI: $10.22358 /$ jafs $/ 66468 / 2008$

POWELL, R., F. GANNON (2002): Purification of DNA by phenol extraction and ethanol precipitation. Oxford University Press, Vol. 180, United Kingdom, pp. 52-63.

PRINZENBERG, E. M., I. KRAUSEL, G. ERHARDT (1999): SSCP analysis at the bovine CSN3 locus discriminates six alleles corresponding to known protein variants (A, B, C, E, F, G) and three new DNA polymorphisms (H, I, A1). Anim. Biotechnol. 10, 49-62.

DOI: $10.1080 / 10495399909525921$

PRINZENBERG E. M, K. GUTSCHER, S. CHESSA, A. CAROLI, G. ERHARDT (2005): Caprine $\kappa$-Casein (CSN3) Polymorphism: new developments in molecular knowledge. J. Dairy Sci. 88, 1490-1498.

DOI: 10.3168/JDS.S0022-0302(05)72817-4

SELVAGGI, M., V. LAUDADIO, C. DARIO, V. TUFARELLI (2014): Major proteins in goat milk: an updated overview on genetic variability. Mol. Biol. Rep. 41, 1035-1048.

DOI: 10.1007/s11033-013-2949-9. Epub 2014 Jan 1

STRZELEC, E., R. NIŻNIKOWSKI (2011): SNPs polymorphisms in LGB, CSN3 and GHR genes in five goat breeds kept in Poland. Ann. Warsaw Univ. of Life Sc. -SGGW, Anim. Sci. 49, 181-188.

DOI: $10.1007 / \mathrm{s} 11033-013-2949-9$

SZTANKÓOVÁ, Z., J. RYCHTÁŘOVÁ, J. KYSELOVÁ, V. MÁTLOVÁ, M. ŠTIPKOVÁ, J. MATEJIČKOVÁ, M. MARKOVÁ (2009): Effect of the $\alpha$ s1-, $\alpha$ s2-, $\beta$ - and $\kappa$-casein genotypes on the milk production parameters in Czech goat dairy breeds. Grant J. ETTN 072-11-00002-094, 76-80.

TOLU, C., I. Y. YURTMAN, T. SAVAS (2010): Comparison of Gökçeada, Maltese and Turkish Saanen goat genotypes in terms of milk yield characteristics. J. Anim. Prod. 51, 8-15 (in Turkish).

TORRES-VÁZQUEZ, J. A., M. VALENCIA-POSADAS, H. CASTILLO-JUÁREZ, H. MONTALDO (2009): Genetic and phenotypic parameters of milk yield, milk composition and age at first kidding in Saanen goats from Mexico. Livest. Sci. 126, 147-153.

DOI: $10.1016 /$ j.livsci.2009.06.008 
TZIBOULA-CLARKE A (2003): Encyclopedia of Dairy Sciences: Goat milk. Academic Press, Cornwall, pp. 12701279 .

ULUTAS, Z., M. KURAN, E. SİRIN, Y. AKSOY (2010): Determination of offspring, milk yield and development characteristics of goats of Saanen breed goats raised under Tokat conditions. Prooceding of National Goat Breeding Congress, July, Canakkale, Turkey, pp. 215-218 (in Turkish).

VLAD, I., M. MAFTEI, D. IANIȚKI, M. STANCIU, A. FIȚA (2014): Morpho-productive Characteristics of Saanen Goats in the South of Romania. Sci. Pap. Anim. Sci. Biotech. 47, 301-305.

YAHYAOUI, M. H., A. COLL, A. SANCHEZ, J. M. FOLCH (2001): Genetic polymorphism of the caprine kappa casein gene. J. Dairy Res. 68, 209-216.

DOI: $10.1017 / \mathrm{S} 0022029901004733$

YAHYAOUI, M. H., A. ANGIOLILlO, F. PILLA, A. SANCHEZ, J. M. FOLCH (2003): Characterization and geno-typing of the caprine k-casein variants. J. Dairy Sci. 86, 2715-2720.

DOI:10.3168/jds.S0022-0302(03)73867-3
YE, G. M., C. CHEN, S. HUANG, D. D. HAN (2005): Cloning and characterization a novel human 1-acyl-sn-glycerol-3phosphate acyltransferase gene AGPAT7. DNA Seq. 16, 386-390.

DOI: $10.1080 / 10425170500213712$

YEH, F. C., R. C. YANG, T. B. J. BOYLE, Z. H. YE, J. X. MAO (2000): Popgene (v.1.32) the user-friendly shareware for population genetic analysis University of Alberta, Canada: Avaible at: http://www.ualberta.ca/ fyeh/, (Accessed: January 01, 2015.)

ZOA-MBOE A., C. MICHAUX, X. J. C. DEILleU, C. KEBERS', F. P. FARNIR, P. L. LEROY (1997): Effects of parity, breed, herd-year, age, and month of kidding on the milk yield and composition of dairy goats in Belgium. J. Anim. Breed Genet. 114, 201-213.

DOI: 10.1111/j.1439-0388.1997.tb00506.x

Received: 31 October 2019

Accepted: 2 October 2020

\section{DINCEL, D., S. ARDICLI, H. SAMLI, M. M. OGAN, F. BALCI: Procjena nekih čimbenika okoliša i genetskih čimbenika (CSN3 i AGPAT6) na prinos i sastav mlijeka u sanske koze. Vet. arhiv 91, 19-30, 2021. \\ SAŽETAK}

Istraživanje je provedeno kako bi se odredili učinci čimbenika okoliša te učinci genskih polimorfizama CSN3 i AGPAT6 na prinos i sastav mlijeka u sanske koze. Tijekom laktacije koza provedena je genotipizacija te prikupljani uzorci za utvrđivanje prinosa i sastava mlijeka. Genotipovi gena CSN3 i AGPAT6 određeni su PCR-RFLP-om. Prinos mlijeka (MY), duljina laktacije (LL), udio proteina, udio masnoće, udio suhe tvari (TS), udio nemasne suhe tvari (SNF), udio kazeina, udio laktoze bili su kako slijedi: 388,9 $\pm 17,5 \mathrm{~kg}, 243 \pm 5,81$ dana, 3,29 $\pm 0,05 \%, 3,59 \pm 0,07 \%$, $11,60 \pm 0,13 \%, 8,43 \pm 0,06 \%, 2,57 \pm 0,04 \%, 4,31 \pm 0,03 \%$. Prinos u kg za protein, masnoću, suhu tvar, nemasnu suhu tvar, kazein i laktozu bili su kako slijedi: $11,21 \pm 0,47 \mathrm{~kg}, 12,79 \pm 0,64 \mathrm{~kg}, 40,95 \pm 1,82 \mathrm{~kg}, 29,53 \pm 1,31 \mathrm{~kg}$, $8,82 \pm 0,37 \mathrm{~kg}, 15,40 \pm 0,74 \mathrm{~kg}$. Utvrđeni genotipovi i učestalost alela gena CSN3 i AGPAT6 bili su: FF $(99,20 \%)$, MF $(0,80 \%), F(0,996), M(0,004)$, GG $(12 \%)$, GC (43,20\%), CC (44,80\%), G $(0,336), C(0,664)$. Statistički znakoviti utjecaji utvrđeni su za: duljinu laktacije na pokazatelje prinosa mlijeka (proteine, masnoću, TS, SNF, kazein, laktozu, MY) $(\mathrm{P}<0,001)$; dobi na pokazatelje prinosa mlijeka $(\mathrm{P}<0,001)$ zatim na proteine, masnoću, SNF, udio kazeina $(\mathrm{P}<0,05)$, te na udio suhe tvari i duljinu laktacije $(\mathrm{P}<0,01)$. Tip legla nije znakovito utjecao na pokazatelje prinosa mlijeka. Istražene sanske koze pokazale su varijacije gena AGPAT6 (g.9263C $>\mathrm{G})$, dok je stado za gen CSN3 bilo monomorfno (FF). Učinak gena AGPAT6 na svojstva mlijeka nije bio statistički znakovit. Čimbenici kao što su dob majke i duljina laktacije znakovito su utjecali na svojstva mlijeka sanske koze, stoga bi oni mogli biti korisni za unapređenje uzgojnih strategija mliječnih pasmina koza.

Ključne riječi: prinos i sastav mlijeka; PCR-RFLP; sanska koza; CSN3; AGPAT6 